\title{
Deteksi dan Identifikasi Potyvirus pada Ubi Jalar di Tana Toraja, Sulawesi Selatan
}

\author{
Detection and Identification of Potyvirus on Sweet Potato \\ in Tana Toraja, South Sulawesi
}

Laras Anjarsari, Gede Suastika*, Tri Asmira Damayanti

Institut Pertanian Bogor, Bogor 16680

\begin{abstract}
ABSTRAK
Pada pertanaman ubi jalar di Kabupaten Tana Toraja, Sulawesi Selatan ditemukan gejala berupa klorosis pada tulang daun, bercak keunguan yang tidak merata pada lamina, namun ukuran daun normal. Untuk mengetahui penyebab penyakit tersebut dilakukan deteksi asam nukleat dengan teknik reverse transcription-polymerase chain reaction (RT-PCR) dan perunutan DNA. RT-PCR menggunakan primer universal Potyvirus yang mendeteksi gen CI berhasil mengamplifikasi DNA dengan ukuran sekitar 683 pb. Perunutan DNA gen CI tersebut menunjukkan homologi sebesar $98 \%$ dengan Sweet potato virus $G$ (SPVG). SPVG juga berhasil dikonfirmasi dengan RT-PCR dan perunutan DNA menggunakan primer spesifik gen protein selubung SPVG. Analisis nukleotida dan asam amino gen CP SPVG menunjukkan bahwa SPVG asal Tana Toraja memiliki homologi paling tinggi dengan SPVG isolat dari negara Jepang dengan homologi sebesar 99.2\%. Laporan ini merupakan laporan pertama infeksi SPVG di Tana Toraja

Kata kunci: bercak lamina, klorosis, RT-PCR, Sweet potato virus $G$
\end{abstract}

\begin{abstract}
Typical viral symptoms including chlorotic and uneven interveinal yellowing on leaves without leaf malformation was observed on sweet potato field in Tana Toraja, South Sulawesi. To identify the causal of the disease, reverse transcription-polymerase chain reaction (RT-PCR) and DNA sequencing were carried out to detect the virus from infected plants. RT-PCR using universal primer for C1 gene of Potyvirus was successfully amplified approximately 683bp DNA fragment. The nucleotide sequences of this $\mathrm{C} 1$ gene fragment showed $98 \%$ homology to Sweet potato virus $G$ (SPVG). Amplification using specific primer for coat protein (CP) gene of SPVG followed by DNA sequencing confirmed the association of SPVG from infected plants. Further nucleotide analysis shwowed that SPVG isolate from Tana Toraja had $99.2 \%$ homology to isolate from Japan. This is the firstt report of SPVG infection on sweet potato in South Sulawesi.
\end{abstract}

Key words: chlorosis, leaf spot, RT-PCR, Sweet potato virus $G$

\section{PENDAHULUAN}

Ubi jalar merupakan tanaman pangan umbi-umbian terpenting ketiga di dunia dan makanan pokok paling populer keempat di negara berkembang termasuk Indonesia
(FAO 2000). Di Indonesia, ubi jalar menjadi makanan pokok masyarakat Indonesia bagian timur, seperti di Papua. Ubi jalar mengandung serat, kalium, magnesium, zat besi, vitamin $A$, vitamin $C$, vitamin $D$, vitamin $E$, serta vitamin B6 yang bermanfaat mencegah

${ }^{*}$ Alamat penulis korespondensi: Departemen Proteksi Tanaman, Fakultas Pertanian, Institut Pertanian Bogor, Jalan Kamper, Kampus Darmaga, Bogor 16680

Tel: 0251 8629364, Faks:0251 8629362, Surel: gedesuast@yahoo.com 
penyakit jantung dan stroke (Suismono 1995). Kebutuhan akan sumber karbohidrat yang satu ini semakin meningkat seiring dengan digalakkannya program diversifikasi pangan oleh pemerintah.

Beberapa penyakit ubi jalar di Indonesia di antaranya kudis, layu fusarium, bercak daun, hawar daun, busuk hitam, layu bakteri dan nematoda. Selain itu, ubi jalar juga dilaporkan terserang penyakit yang disebabkan oleh virus. Beberapa virus penting pada ubi jalar yang dilaporkan di beberapa negara ialah Sweet potato feathery mottle virus (SPFMV), Sweet potato feathery mottle virus strain internal cork (SPFMV-IC), Sweet potato feathery mottle virus strain russet crack (SPFMV-RC), Sweet potato mild mottle virus (SPMMV), Sweet potato chlorotic stunt virus (SPCSV) (Abad et al. 2007), dan Sweet potato virus $G$ (SPVG) (Kwak et al. 2007; Karyeija et al. 1998; Rannali et al. 2008; Souto et al. 2003; Yinghong et al. 2006). Infeksi Sweet potato virus disease (SPVD) merupakan interaksi sinergistik antara SPCSV dan SPFMV. Infeksi SPVD ini dapat menurunkan hasil panen hingga 90\% di Afrika bagian timur (Karyeija et al. 1998).

Di Indonesia beberapa virus yang menyerang ubi jalar telah dilaporkan, seperti SPFMV dan SPCSV di Jawa Barat dan Jawa Timur dengan gejala berupa pemucatan tulang daun dan tanaman menjadi kerdil. Hasil survei yang kami lakukan pada tahun 2013 di daerah pertanaman ubi jalar di Kabupaten Tana
Toraja, Provinsi Sulawesi Selatan terdapat beberapa tanaman yang menunjukkan gejala berupa klorosis pada tulang daun, bercak keunguan yang tidak merata pada lamina daun, tetapi ukuran daun masih relatif normal (Gambar 1). Berdasarkan gejala yang ditimbulkannya, tanaman ubi jalar tersebut diduga terinfeksi oleh virus, walaupun gejala yang ditimbulkan berbeda dengan yang telah dilaporkan sebelumnya.

Deteksi dan identifikasi penyebab gejala klorosis dan bercak keunguan pada ubi jalar perlu dilakukan untuk membuktikan penyebab penyakit tersebut adalah virus sehingga strategi pengendalian dapat dilakukan dengan tepat dan epidemi penyakit dapat dicegah.

\section{BAHAN DAN METODE}

\section{Ekstraksi RNA}

Ekstraksi RNA total menggunakan Xprep Plant RNA Mini Kit (Phile Korea) prosedur sesuai dengan protokol. Sebanyak $0.1 \mathrm{~g}$ daun bergejala ditambahi nitrogen cair dan digerus dengan mortar hingga menjadi serbuk. Serbuk kemudian ditambah dengan $450 \mu \mathrm{L}$ bufer XPRB yang mengandung $1 \%$ $\beta$-mercaptoetanol dan dicampur sampai homogen. Campuran tersebut dipindahkan ke dalam tabung ependorf dan disentrifugasi pada 4000 g selama 2 menit. Supernatan dipindahkan ke dalam tabung ependorf baru yang berisi $250 \mu \mathrm{L}$ etanol $96 \%$ dan dicampur hingga homogen. Campuran supernatan dan

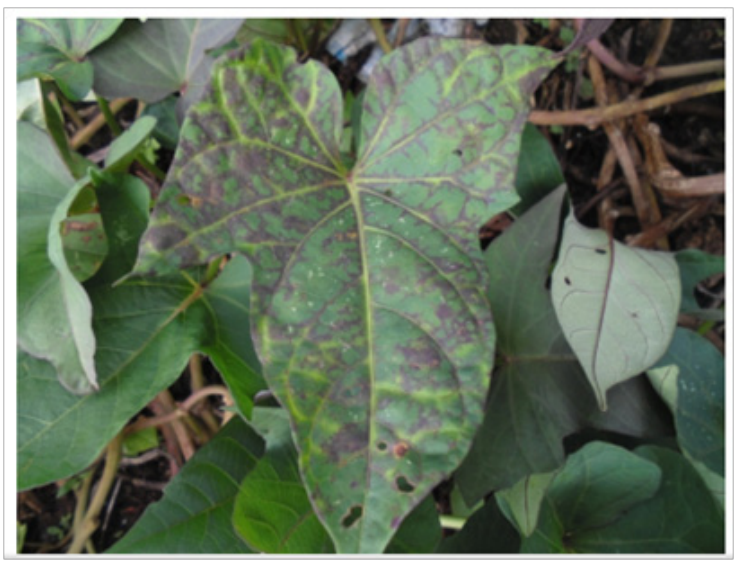

Gambar 1 Gejala klorosis tulang daun dan bercak keunguan pada lamina daun ubi jalar yang ditemukan pada pertanaman ubi jalar di Tana Toraja, Sulawesi Selatan. 
etanol 96\% tersebut dimasukkan ke dalam kolom XPPLR merah muda yang ditempatkan pada tabung eppendorf, dan disentrifugasi pada 4000 g selama 1 menit. RNA akan terperangkap pada kolom dan cairan pada tabung eppendorf dibuang. Selanjutnya ditambahkan $500 \mu \mathrm{L} 1 \mathrm{ke}$ dalam kolom XPPLR dan disentrifugasi pada 4000 g selama 1 menit. Cairan pada tabung eppendorf dibuang, kemudian ditambahkan $750 \mu \mathrm{L}$ bufer 2 ke dalam kolom XPPLR yang telah ditempatkan dalam tabung eppendorf baru. Selanjutnya cairan tersebut disentrifugasi pada 5000 g selama 1 menit untuk pengeringan. RNA total yang terperangkap pada bagian tengah membran kolom diekstraksi dengan menambahkan $50 \mu \mathrm{L}$ air bebas nuklease dan didiamkan selama 1 menit. Sentrifugasi pada 4000 g selama 2 menit. RNA total yang terekstraksi digunakan sebagai templat dalam reaksi RT-PCR.

\section{Sintesis cDNA}

RNA hasil ekstraksi ditranskripsi balik. Setiap $10 \mu \mathrm{L}$ reaksi transkripsi balik terdiri atas $2 \mu \mathrm{L} \mathrm{H}_{2} \mathrm{O}$ bebas nuklease, $0.5 \mu \mathrm{L}$ dNTP $10 \mathrm{mM}, 1 \mu \mathrm{L}$ Oligo d(T) $10 \mathrm{mM}, 2 \mu \mathrm{L}$ bufer RT 5x, 0.5 $\mu$ L DTT $0.1 \mathrm{M}, 0.5 \mu \mathrm{L}$ M-MuLV (Thermo), $0.5 \mu \mathrm{L}$ ribolock (Thermo), dan $3 \mu \mathrm{L}$ RNA templat. Transkripsi balik RNA dilakukan pada suhu $42{ }^{\circ} \mathrm{C}$ selama 1 jam dan pada suhu $70^{\circ} \mathrm{C}$ selama 10 menit. cDNA yang dihasilkan digunakan sebagai templat DNA dalam reaksi PCR.

\section{RT-PCR}

cDNA diamplifikasi dengan teknik pada reaksi campuran dengan total volume $25 \mu \mathrm{L}$ yang terdiri atas $8.5 \mu \mathrm{L}$ air bebas nuklease, 12.5 $\mu \mathrm{L}$ PCR mix (Thermo), masing-masing $1 \mu \mathrm{L} 10 \mathrm{mM}$ primer forward, dan primer reverse, dan $2 \mu \mathrm{L}$ cDNA. Tahapan amplifikasi DNA menggunakan beberapa pasangan primer, yaitu primer universal untuk Potyvirus, yaitu MJ1/MJ2 dengan siklus amplifikasi berdasarkan metode PCR, seperti yang dilaporkan oleh Marie-Jeanne et al. (2000), pasangan primer CIREF dan CIFOR yang sangat spesifik untuk mendeteksi gen cylindrical inclusion (CI) anggota genus Potyvirus (Ha et al. 2008), serta pasangan primer spesifik untuk mendeteksi gen coat protein (CP) SPVG, yaitu SPVG-CPF dan SPVG-CPR (Tabel 1).

cDNA diamplifikasi dengan teknik PCR. Setiap reaksi PCR $(25 \mu \mathrm{L})$ terdiri atas $2 \mu \mathrm{L}$ cDNA, $12.5 \mu \mathrm{L}$ PCR Mix (Thermo), $1 \mu \mathrm{L}$ masing-masing primer $10 \mathrm{mM}$ dan $8.5 \mu \mathrm{L}$ air bebas nuklease. Amplifikasi cDNA dengan teknik PCR berdasarkan pada dua metode.

Metode Marie-Jeanne et al. (2000) menggunakan primer MJ1 dan MJ2 yang merupakan primer universal untuk Potyvirus (Tabel 1). Amplifikasi cDNA dilakukan sebanyak 35 siklus melalui tiga tahapan, yaitu pemisahan utas DNA (denaturasi) pada $94{ }^{\circ} \mathrm{C}$ selama 30 detik, penempelan primer (annealing) primer pada $50{ }^{\circ} \mathrm{C}$ selama 1 menit dan perpanjangan DNA (sintesis) pada 72 ${ }^{\circ} \mathrm{C}$ selama 1 menit, kemudian khusus untuk siklus terakhir ditambah tahapan sintesis 72 ${ }^{\circ} \mathrm{C}$ selama 10 menit.

Metode Ha et al. (2008) menggunakan pasangan primer CIFOR dan CIREV (Tabel 1) yang sangat spesifik untuk mendeteksi gen cylindrical inclusion (CI) anggota genus Potyvirus. Amplifikasi cDNA dimulai dari predenaturasi pada suhu $94^{\circ} \mathrm{C}$ selama 3 menit sebanyak 1 siklus dan dilanjutkan sebanyak 40 siklus yang terdiri atas denaturasi pada 94 ${ }^{\circ} \mathrm{C}$ selama 1 menit, penempelan pada $40{ }^{\circ} \mathrm{C}$ selama 30 detik, dan sintesis DNA pada 68 ${ }^{\circ} \mathrm{C}$ selama 1 menit. Siklus terakhir ditambah tahapan sintesis $68^{\circ} \mathrm{C}$ selama 5 menit.

Pasangan primer SPVG-CPf dan SPVGCPr (Tabel 1) merupakan primer spesifik untuk mendeteksi gen coat protein (CP) SPVG. Amplifikasi cDNA dengan PCR dimulai dengan tahapan predenaturasi pada suhu $94^{\circ} \mathrm{C}$ selama 1 menit sebanyak 1 siklus. Tahapan selanjutnya sebanyak 30 siklus yang terdiri atas denaturasi pada $94{ }^{\circ} \mathrm{C}$ selama 30 detik, penempelan pada $55{ }^{\circ} \mathrm{C}$ selama 30 detik, dan sintesis DNA pada $72{ }^{\circ} \mathrm{C}$ selama 1 menit. Siklus terakhir pada tahapan sintesis 72 ${ }^{\circ} \mathrm{C}$ selama 2 menit. 
Tabel 1 Sikuen primer yang digunakan untuk deteksi virus penyebab klorosis ubi jalar

\begin{tabular}{llc}
\hline Primer & \multicolumn{1}{c}{ Urutan basa } & $\begin{array}{c}\text { Ukuran } \\
(\mathrm{pb})\end{array}$ \\
\hline MJ1 & 5'-TGGTHTGGTGYATHGARAAYGG-3' & $\sim 320$ \\
MJ2 & 5'-TGCTGCKGCYTTCATYTG-3' & \\
CIFOR & 5'-GGI VVI GTI GGI WSI GGI AAR TCI AC -3' & $\sim 683$ \\
CIREF & 5'-ACI CCR TTY TCD ATD ATR TTI GTI GC -3' & \\
SPVG-CPF & 5'-AATTAAGGATCCTCTGCTGAAGAGATATACGATGC-3' & \\
SPVG-CPR & 5'-AATTAAA_AGCTTCTGCACACCCCTCATACCCAAG-3' & \\
\hline
\end{tabular}

\section{Visualisasi DNA}

Visualisasi fragmen DNA hasil amplifikasi PCR dielektroforesis pada gel agarosa $1 \%$ dalam bufer Tris-borate (TBE) $0.5 \mathrm{X}$ dengan tegangan 100 voltselama20menit. Pengamatan dilakukan dengan UV transluminator setelah direndam dalam larutan etidium bromida $2 \%$ selama 15 menit.

\section{Perunutan dan Analisis Susunan Nukleotida}

Perunutan susunan nukleotida dilakukan di First Base, Singapura. Hasil sekuen dianalisis menggunakan program basic local alignment search tool (BLAST) (www.ncbi.nml.niv. gov) dan perangkat lunak Wu-Blastn (www. ebi.ac.uk). Hasil perunutan asam nukleat virus akan dibandingkan dengan tingkat homologi sekuennya dengan beberapa virus lain yang sekuennya telah terdaftar pada Gene Bank. Matriks identitas nukleotida dan asam amino dibuat menggunakan program perangkat lunak BioEdit (Hall 1999). Pohon filogenetik berdasarkan runutan nukleotida dan asam amino gen $\mathrm{CP}$ dibuat menggunakan perangkat lunak molecular evolutionary genetic analysis software (MEGA) 5.1 menggunakan UPGMA tree dengan bootstrap sebanyak 1000 kali.

\section{HASIL}

\section{Virus yang Menginfeksi Ubi Jalar}

Amplifikasi cDNA yang berasal dari RNA total tanaman ubi jalar yang terinfeksi virus dengan teknik PCR menggunakan 3 pasang primer (Tabel 1) berhasil teramplifikasi.
Fragmen DNA yang berukuran $\approx 320 \mathrm{pb}$ berhasil teramplifikasi dari pasangan primer universal untuk Potyvirus (MJ1 dan MJ2) (data tidak ditampilkan). Fragmen DNA berukuran $\approx 683 \mathrm{pb}$ (Gambar 2) teramplifikasi dari pasangan primer CIFOR dan CIREV yang merupakan primer spesifik mendeteksi gen CI anggota Potyvirus, sedangkan fragmen DNA berukuran $\approx 1064 \mathrm{pb}$ (Gambar 2) teramplifikasi dari pasangan primer SPVGCPf dan SPVG-CPr yang merupakan primer spesifik mendeteksi gen CP SPVG.

\section{Sekuensing Runutan DNA dan Analisis Homologi Genetik}

Hasil analisis BLAST (www.ncbi.nml.niv. gov) runutan DNA gen CI berukuran $651 \mathrm{pb}$ menunjukkan homologi dengan Sweet potato virus $G$ (SPVG) sebesar $98 \%$. Analisis runutan DNA gen CP SPVG berhasil merunut DNA berukuran $1050 \mathrm{nt}$ dan mengkode 322 asam amino. Hasil analisis BLAST menunjukkan runutan nukleotida dan asam amino gen $\mathrm{CP}$ SPVG asal ubi jalar Tana Toraja terinfeksi virus homologi sebesar 99.2\% dengan SPVG asal Jepang (Tabel 2 dan 3). Analisis pohon filogenetika menunjukkan bahwa virus yang menginfeksi ubi jalar satu kluster dengan SPVG asal Jepang (Gambar 3a dan 3b).

\section{PEMBAHASAN}

Beberapa virus dilaporkan telah menyerang tanaman ubi jalar, namun hanya sedikit yang telah diteliti lebih jauh. Hal 


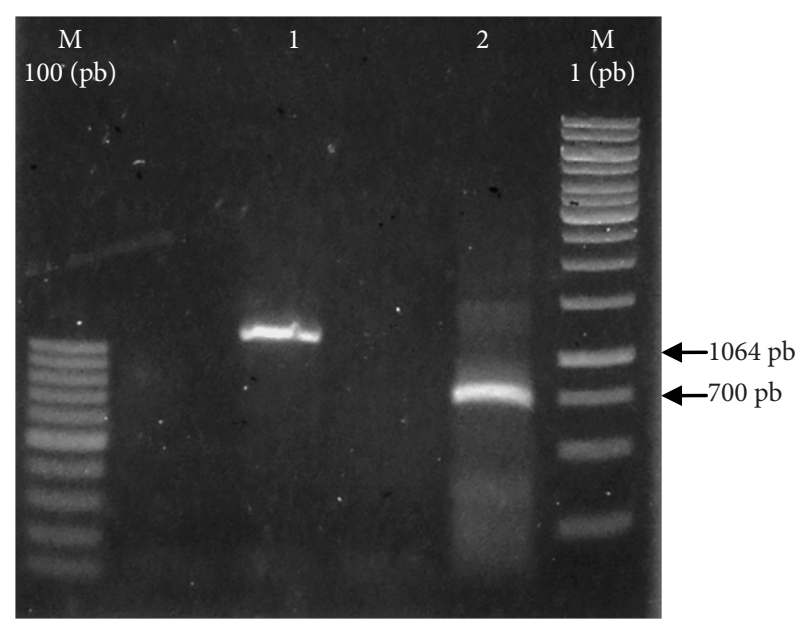

Gambar 2 Visualisasi hasil amplifikasi DNA sampel daun ubi jalar. M, penanda DNA 100 pb dan $1 \mathrm{~kb}$; 1, mengunakan primer spesifik SPVG, 2, menggunakan primer universal gen CI Potyvirus.

tersebut dikarenakan sulitnya mengisolasi dan memurnikan virus dari infeksi campuran dan kompleks yang bersinergi (Collinet et al. 1998). Hingga saat ini, terdapat lebih dari 30 jenis virus yang dimasukkan dalam 9 famili yang diketahui menginfeksi ubi jalar. Dari 30 jenis virus tersebut, 6 di antaranya merupakan anggota Potyvirus, famili Potyviridae (Abad et al. 2007; Aritua et al. 2009; Albuquerque et al. 2011). Pada umumnya virus yang menyerang ubi jalar sulit ditularkan secara mekanis, tidak dapat ditularkan melalui benih, dan kisaran inangnya terbatas pada famili Convolvulaceae (Wolters et al. 1990). Oleh karena itu vektor virus ini, yaitu kutudaun, sangat berperan dalam penularan di lapangan (Wosula et al. 2013). Selain itu, penggunaan bahan perbanyakan vegetatif sebagai metode yang utama memberikan cara penyebaran yang efisien bagi virus selama musim tanam di lahan. Pengaruh infeksi virus pada produktivitas tanaman sangat bervariasi, bergantung pada jenis virus yang menginfeksi, kekompleksan virus, dan kultivar ubi jalar yang terinfeksi (Domola et al. 2008).

Deteksi dan identifikasi tanaman ubi jalar Tana Toraja yang terinfeksi virus berdasarkan teknik PCR menggunakan 3 pasang primer untuk mendeteksi genus Potyvirus, analisis runutan DNA menunjukkan hasil yang konsisten dan membuktikan bahwa virus yang menginfeksi ubi jalar tersebut Sweet potato virus $G$ (SPVG). Analisis pohon filogenetik berdasarkan nukleotida dan asam amino menunjukkan bahwa SPVG asal Tana Toraja

Tabel 2 Homologi sikuen basa nukleotida virus yang menginfeksi ubi jalar di Tana Toraja dengan beberapa sikuen Sweet potato virus G yang tersedia di GenBank

\begin{tabular}{llllllllllll}
\hline \multirow{2}{*}{ Asal negara } & \multirow{2}{*}{ No Aksesi } & \multicolumn{10}{c}{ Tingkat homologi (\%) } \\
\cline { 3 - 10 } & & 1 & 2 & 3 & 4 & 5 & 6 & 7 & 8 & 9 & 10 \\
\hline Indonesia/Idntr & na* & ID & & & & & & & & \\
Indonesia/Idnjv & EU220755.1 & 98.4 & ID & & & & & & & \\
Jepang/Jpg & AB435072.1 & 99.2 & 97.7 & ID & & & & & & \\
Mesir/Msr & AJ515380.1 & 98.0 & 98.6 & 97.3 & ID & & & & & \\
Cina/Chn & KC771333.1 & 98.6 & 99.2 & 97.9 & 98.8 & ID & & & & \\
Argentina/Argtn & JQ824374 & 98.6 & 99.2 & 97.9 & 98.8 & 100 & ID & & & \\
New zealand/Nwzlnd & EF514221.1 & 98.5 & 99.9 & 97.8 & 98.7 & 99.3 & 99.3 & ID & & \\
Belgia/Blg & X76944.1 & 97.9 & 98.4 & 97.1 & 98.2 & 98.6 & 98.6 & 98.5 & ID & & \\
Amerika/Us** & S43450 & 64.6 & 64.7 & 64.3 & 64.9 & 64.8 & 64.8 & 64.8 & 64.2 & ID & \\
Meksiko/Mex*** & L11890.1 & 50.3 & 50.5 & 50.0 & 50.2 & 50.4 & 50.4 & 50.6 & 50.3 & 53.0 & ID \\
\hline *na, belum didaftarkan pada Genbank; ** Virus di luar grup digunakan SPFMV; *** Virus di luar grup digunakan \\
BCMV
\end{tabular}




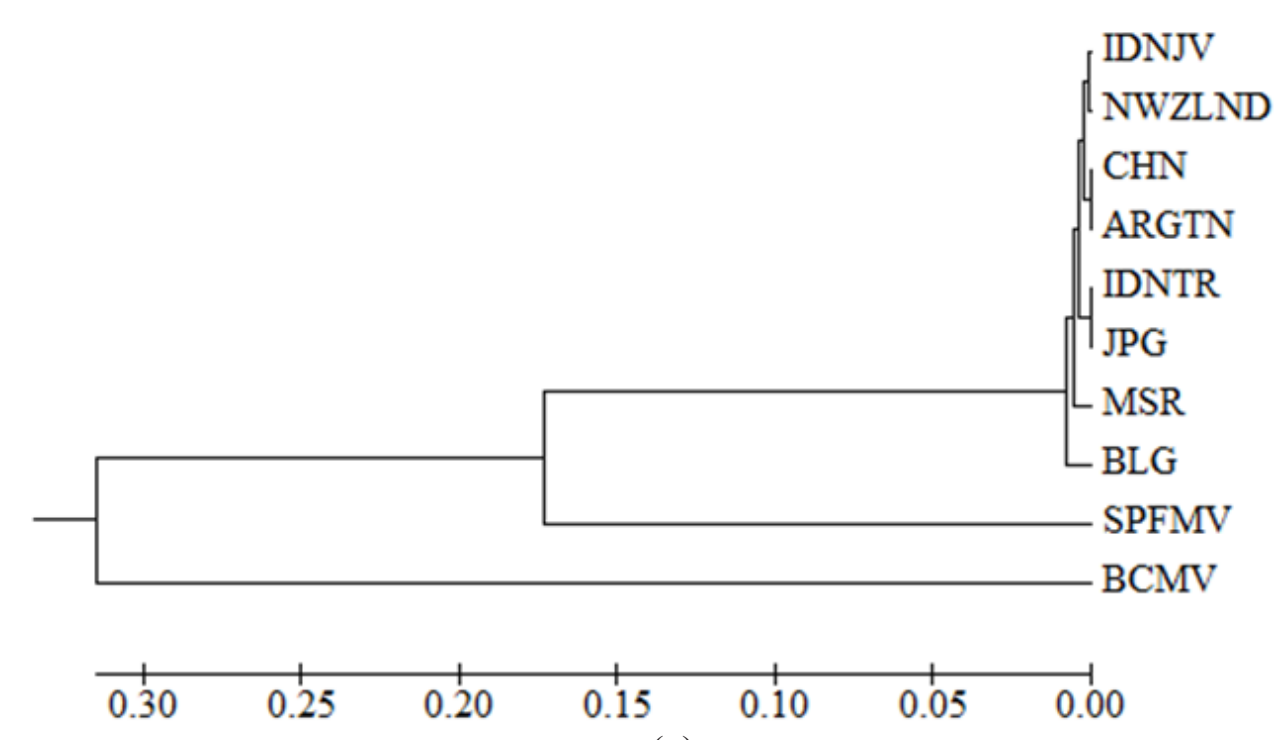

(a)

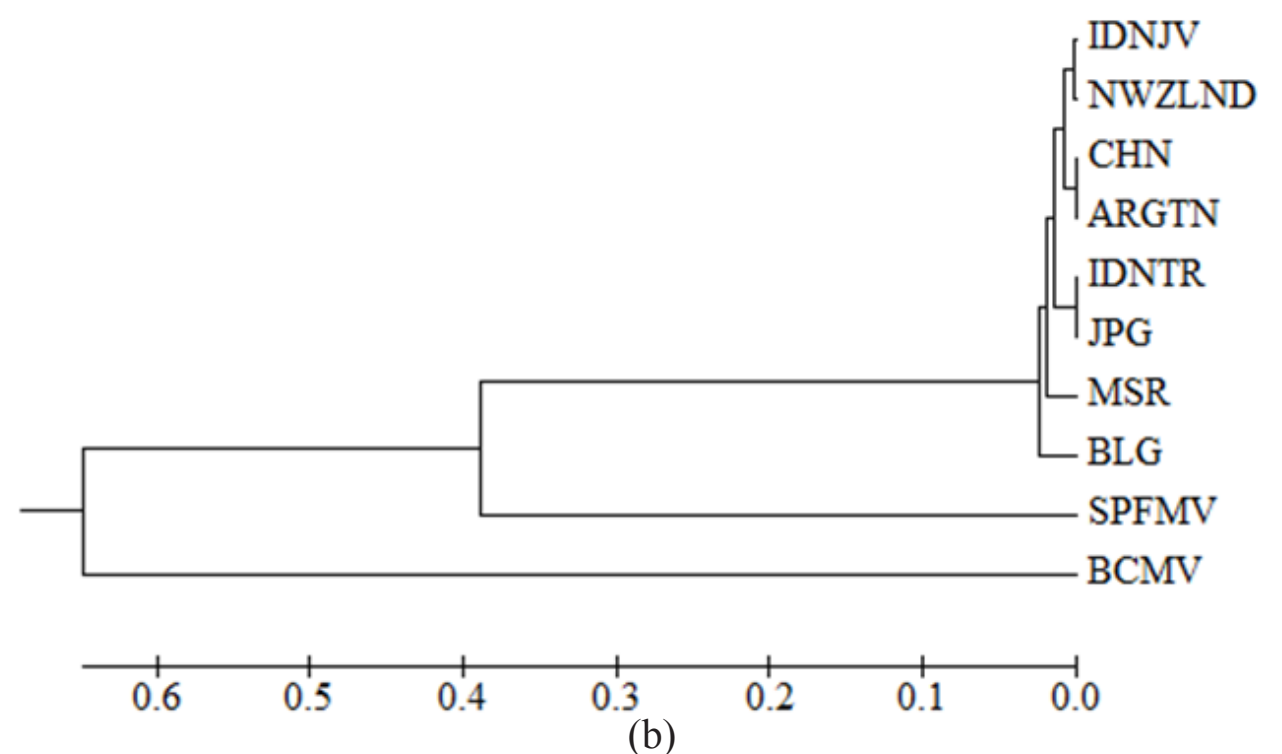

Gambar 3 Pohon filogenetika SPVG Idn-TR dengan isolat SPVG dari negara lain. a,berdasarkan homologi nukleotida dan b, asam amino. SPFMV dan BCMV digunakan sebagai grup luar.

berada dalam kluster yang sama dengan SPVG asal Jepang. Meskipun wilayah Tana Toraja dan Pulau Jawa terletak di Indonesia, namun isolat SPVG asal Toraja memiliki tingkat homologi (99.2\%) dengan isolat SPVG asal Jepang, sedangkan isolat SPVG asal Jawa memiliki homologi yang paling tinggi dengan isolat SPVG asal Selandia Baru (99.9\%). Mengingat sulitnya penularan virus ini secara mekanis, ada indikasi bahwa SPVG masuk ke Indonesia melalui serangga vektor berupa kutudaun (Wosula et al. 2013) atau bahan perbanyakan vegetatif dari luar negeri. Kemungkinan lainnya ialah virus tersebut memang sudah ada di Indonesia, akan tetapi baru dideteksi dan dilaporkan secara tertulis. Tentu saja investigasi mengenai rekam jejak SPVG di Indonesia perlu ditelusuri lebih lanjut.

Secara pasti persentase kehilangan hasil akibat serangan SPVG belum diketahui, namun bila dibandingkan dengan tanaman ubi yang sehat maka akan terlihat perbedaan baik dalam hal ukuran daun, warna daun, dan luasan fotosintesis pada lamina daun. Berkurangnya luasan fotosintesis pada daun akan mengakibatkan penurunan fotosintat yang didistribusikan ke seluruh bagian tanaman sehingga proses pembentukan umbi pun menjadi kurang maksimal. Jika pembentukan 
Tabel 3 Homologi (\%) sikuen asam amino virus yang menginfeksi ubi jalar di Tana Toraja dengan beberapa sikuen Sweet potato virus $G$ (SPVG) yang tersedia di GenBank

\begin{tabular}{|c|c|c|c|c|c|c|c|c|c|c|c|}
\hline \multirow{2}{*}{ Asal negara } & \multirow{2}{*}{ No. Aksesi } & \multicolumn{10}{|c|}{ Tingkat homologi (\%) } \\
\hline & & 1 & 2 & 3 & 4 & 5 & 6 & 7 & 8 & 9 & 10 \\
\hline Indonesia/Idntr & na* & ID & & & & & & & & & \\
\hline Indonesia/Idnjv & EU220755.1 & 96.9 & ID & & & & & & & & \\
\hline Jepang/Jpg & AB435072.1 & 99.2 & 96.2 & ID & & & & & & & \\
\hline Mesir/Msr & AJ515380.1 & 97.2 & 97.9 & 96.5 & ID & & & & & & \\
\hline Cina/Chn & KC771333.1 & 97.5 & 98.2 & 96.8 & 98.5 & ID & & & & & \\
\hline Argentina/Argtn & JQ824374 & 97.5 & 98.2 & 96.8 & 98.5 & 100 & ID & & & & \\
\hline New zealand/Nwzlnd & EF514221.1 & 97.2 & 99.7 & 95.9 & 97.7 & 98.5 & 98.5 & ID & & & \\
\hline Belgia/Blg & X76944.1 & 96.7 & 97.4 & 95.9 & 97.7 & 97.9 & 97.9 & 97.7 & ID & & \\
\hline Amerika/Us** & $\mathrm{S} 43450$ & 59.4 & 60.7 & 59.1 & 60.7 & 60.4 & 60.4 & 60.7 & 59.5 & ID & \\
\hline Meksiko/Mex*** & L11890.1 & 42.0 & 42.5 & 41.7 & 42.6 & 42.6 & 42.6 & 42.8 & 42.1 & $44.6 \mathrm{Il}$ & ID \\
\hline \multicolumn{4}{|c|}{$\begin{array}{l}\text { umbi kurang maksimal maka produktivitas } \\
\text { ubi pun akan menurun. Selain itu tanaman ubi } \\
\text { yang terserang virus pada umumnya bentuk } \\
\text { umbinya mengalami malformasi. } \\
\text { Pengendalian di lapangan tentunya perlu } \\
\text { dilakukan untuk mencegah penyebaran virus } \\
\text { ke area yang lebih luas. Apalagi mengingat } \\
\text { iklim tropik di Indonesia yang sangat sesuai } \\
\text { untuk perkembangbiakan kutudaun sebagai } \\
\text { vektor virus di lapangan. Oleh karena itu, } \\
\text { diperlukan langkah pengendalian yang tepat, } \\
\text { misalnya dengan eliminasi virus. } \\
\text { SPVG merupakan virus RNA dengan rantai }\end{array}$} & \multicolumn{8}{|c|}{$\begin{array}{l}\text { Peraturan Menteri Pertanian Nomor 93/ } \\
\text { Permentan/OT.140/12/2011 tentang Jenis } \\
\text { Organisme Pengganggu Tumbuhan Karantina, } \\
\text { status keberadaan SPVG di Indonesia belum } \\
\text { dapat ditentukan. Hanya SPFMV saja yang } \\
\text { statusnya diketahui, yakni sebagai OPTK A2 } \\
\text { dengan daerah sebaran terbatas di Jawa Tengah } \\
\text { dan Papua. Akan tetapi berdasarkan laporan } \\
\text { Rannali et al. (2008), SPVG (nomor aksesi } \\
\text { EU220755.1) telah ditemukan di Lembang, } \\
\text { Jawa Barat. Tulisan ini merupakan laporan } \\
\text { pertama tentang infeksi SPVG pada ubi jalar } \\
\text { di daerah Tana Toraja, Sulawesi Selatan. }\end{array}$} \\
\hline
\end{tabular}

\section{UCAPAN TERIMA KASIH} famili Potyviridae, genus Potyvirus. SPVG mempunyai ukuran CP yang terbesar di antara anggota Potyvirus lainnya, dengan panjang sekuen nukleotida lengkapnya sekitar 10800 nt (Li et al. 2012). SPVG sebelumnya diketahui hanya terdapat di wilayah Afrika, Cina, dan Amerika Serikat saja, namun sekarang ditemukan pula pada ubi jalar varietas modern dan di daerah Australia, Selandia Baru, serta wilayah Pasifik (Kokkinos dan Clark 2006; Rannali et al. 2008; 2009).

Penelitian terkait penyakit klorosis yang disebabkan oleh SPVG pada tanaman ubi jalar di Indonesia sangat minim. Berdasarkan

Terima kasih kepada Tomohide Natsuaki (Lab Plant Pathology, Univ. Utsunomiya, Jepang) dan Muhammad Taufik (Lab Penyakit Tumbuhan, Univ Haluoleo) atas dokumentasi gejala dan sarannya, serta kepada Fitrianingrum Kurniawati atas bimbingannya dalam pengolahan data sikuen.

\section{DAFTAR PUSTAKA}

Abad JA, Parks J, New SL, Fuentes S, Jester W, Moyer JW. 2007. First report of 
Sweetpotato chlorotic stunt virus (genus Crinivirus, family Closteroviridae) in North Carolina. Plant Dis. 91:327. DOI: http:// dx.doi.org/10.1094/PDIS-91-3-0327B.

Albuquerque LC, Inoue-Nakata AK, Pinheiro B, Ribeiro SD, Resende RO, Moriones E, Navas-Castillo J. 2011. A novel monopartite begomovirus infecting sweet potato in Brazil. Arch Virol. 156(7):12911294. DOI: http://dx.doi.org/10.1007/ s00705-011-1016-x.

Aritua V, Barg E, Adipala E, Gibson RW, Lesemann DE, Vetten HD. 2009. Host range, purification, and genetic variability in Sweet potato chlorotic fleck virus. Plant Dis. 93(1):87-93. DOI: http://dx.doi. org/10.1094/PDIS-93-1-0087.

Colinet D, Nguyen M, Kummert J, Lepoivre P, Xia FZ. 1998. Differentiation among potyviruses infecting sweet potato based on genus- and virus-spesefic reverse transcription polymerase chain reaction. Plant Dis. 82:223-229. DOI: http://dx.doi. org/10.1094/PDIS.1998.82.2.223.

Domola MJ, Thompson GJ, Aveling TAS, Laurie SM, Strydom H, Van den Berg AA. 2008. Sweet potato viruses in south Africa and the effect of viral infection on storage root yield. Afr Plant Protec 14: 15-23.

Food and Agricultural Organization [FAO]. 2000. Food and Agricultural Organization statistics. Roma(IT): Food and Agricultural Organization of the United nations.

Ha C, Coombs S, revill PA, Harding RM, Vu M, Dale JL. 2008. Design and application of two novel degenerate primer pairs for the detection and complete genomic characterization of Potyviruses. Arch Virol. 53(1):25-36. DOI: http://dx.doi. org/10.1007/s00705-007-1053-7.

Hall TA. 1999. BioEdit: a user friendly biological sequence alignment editor and analysis program for Window.

Karyeija RF, Gibson RW, Valkonen JPT. 1998. The significance of Sweet potato feathery mottle virus in subsistence sweet potato production in Africa. Plant Dis. 82:4-15. DOI: http://dx.doi.org/10.1094/ PDIS.1998.82.1.4.
Kokkinos CD, Clark CA. 2006. Real-time PCR assays for detection and quantification of sweetpotato viruses. Plant Dis. 90:783-788. DOI: http://dx.doi.org/10.1094/PD-90-0783.

Kwak HR, Kim MK, Jung MN, Lee SH, Park JW, Kim KH, Ko SJ, Choi HS. 2007. Genetic diversity of Sweet potato feathery mottle virus from sweet potatoes in Korea. Plant Pathol. J. 23:13-21. DOI: http:// dx.doi.org/10.5423/PPJ.2007.23.1.013.

Li F, Xu D, Abad JA, Li R. 2012. Phylogenetic relationships of closely related potyviruses infecting sweet potato determined by genomic characterization of Sweet potato virus $G$ and Sweet potato virus 2. Virus Genes 45:118-125. DOI: http://dx.doi. org/10.1007/s11262-012-0749-2.

Marie-Jeanne V, Ioos R, Peyre J, Alliot B, Signoret P. 2000. Differentiation of Poaceae Potyviruses by reverse transcriptionpolymerase chain reaction and restriction analysis. J Phytopathol. 148:141-151. DOI: http://dx.doi.org/10.1046/j.14390434.2000.00473.x.

Rannali M, Czekaj V, Jones RAC, Fletcher JD, Mu L, Davis R, Gweyer DI, Coutts B, Valkonen JPT. 2008. Molecular genetic characterization of Sweet potato virus $G$ (SPVG) isolates from the areas of the Pacific Ocean and southern Africa. Plant Dis. 92:1313-1320. DOI: http://dx.doi. org/10.1094/PDIS-92-9-1313.

Rannali M, Czekaj V, Jones RAC, Fletcher JD, Davis RI, Mu L, Valkonen JPT. 2009. Molecular characterization of Sweet potato feathery mottle virus (SPFMV) isolates from Easter Island, French Polynesia, New Zealand, and Southern Africa. Plant Dis. 93:933-939. DOI: http:// dx.doi.org/10.1094/PDIS-93-9-0933.

Souto ER, Sim J, Chen J, Valverde RA, Clark RA. 2003. Properties of strains of Sweet potato feathery mottle virus and two newly recognize potyviruses infecting sweet potato in the United States. Plant Dis. 87:1226-1232. DOI: http://dx.doi. org/10.1094/PDIS.2003.87.10.1226 .

Suismono. 1995. Sweetpotato processing for flour and noodles [tesis]. Bogor (ID): 
Institut Pertanian Bogor.

Wolters P, Collins W, Moyer JW. 1990.

Probable lack of seed transmission of Sweet potato feathery mottle virus in sweet potato. Hort Sci. 25:448-449.

Wosula EN, Davis JA, Clark CA, Smith TP, Arancibia RA, Musser FR, and Reed JT. 2013. The role of aphid abundance, species diversity, and virus titer in the spread of sweetpotato potyviruses in Louisiana and Mississippi. Plant Dis. 97:53-61. DOI: http://dx.doi.org/10.1094/PDIS-06-120564-RE

Yinghong G, Haoru T, Yizheng Z. 2006. Cloning and sequence analysis of coat protein gene of Sweet potato virus $G$. Chinese Agric Sci Bull. 22:50-55. 